\title{
O cinema como prática social: o gênero filme na formação crítico-reflexiva de professores de línguas ${ }^{1}$
}

\author{
Lauro Sérgio Machado Pereira \\ Instituto Federal do Norte de Minas Gerais \\ lauropereiraifnmg@gmail.com
}

Maria da Glória Magalhães dos Reis

Universidade de Brasília

gloriamagalhaes@gmail.com

\section{Resumo}

A relevância pedagógica do cinema tem interessado a pesquisadores de diferentes campos das Ciências Humanas, o que reflete em pesquisas que enfocam a relação do cinema com a educação, o ensino-aprendizagem de línguas e a formação docente. Nesse sentido, com o propósito de contribuir com trabalhos já existentes, este artigo aborda a prática crítico-reflexiva na formação de professores de línguas e toma o filme como um gênero discursivo em potencial. A partir de postulados do dialogismo sociodiscursivo e da teoria de gêneros do discurso, investigamos como o filme pode ser aplicado à formação de professores de línguas, suscitando reflexões críticas sobre a prática desses profissionais. Para tanto, o modelo de sequências didáticas se apresentou pertinente, de modo que elaboramos uma proposta com o filme $\mathrm{O}$ Substituto (2011) e a aplicamos em um curso temático orientado pela metodologia pesquisa-ação, no qual realizamos atividades como sessão de visionamento do filme, discussões temáticas dialogadas com textos teóricos e uma entrevista focalizada. $\mathrm{Na}$ discussão dos dados, indicamos que as sequências didáticas são produtivas para o trabalho com filmes enquanto recurso pedagógico, visto que possibilitaram o engajamento efetivo das participantes nas reflexões.

Palavras-chave: Cinema; Filmes; Gênero discursivo; Professores de línguas; Pesquisa-ação.

1 Este artigo é um recorte atualizado da dissertação de mestrado do primeiro autor (PEREIRA, 2014). Disponível em: 〈https://repositorio.unb.br/handle/10482/17969〉. 


\begin{abstract}
The pedagogical relevance of cinema has interested researchers from different fields of the Human Sciences, which is reflected in research that focuses on the relationship between cinema and education, language teaching and learning and teacher education. In this sense, with the purpose of contributing to the existing works, this article discusses the critical-reflective practice in language teacher education and takes the film as a potential discursive genre. Based on postulates of sociodiscursive dialogism and the theory of discourse genres, we investigate how the film can be applied to the language teacher education, raising critical reflections on the practice of these professionals. For that, the didactic sequences model was relevant, so we elaborated a proposal with the film Detachment (2011) and applied it in a thematic course guided by the Action-Research methodology, in which we carried out activities such as film viewing, thematic discussions dialogued with theoretical texts and a focused interview. The discussion of the data indicated that the didactic sequences are productive for working with films as a pedagogical resource, since they enabled the effective engagement of the participants in the reflections.
\end{abstract}

Keywords: Cinema; Films; Discursive genre; Language teachers; Action research.

\title{
1 Introdução
}

A pertinência de uso dos gêneros discursivos como instrumentos que medeiam processos de aquisição de línguas tem sido bastante discutida pela comunidade de pesquisadores na Linguística Aplicada (doravante LA). As potencialidades dos gêneros respaldam-se em suas próprias características, pois são estruturas textuais relativamente estáveis em circulação na sociedade (BAKHTIN, 2011) e servem a um propósito comunicacional dos falantes em uma situação específica. Em vista disso, ao serem levados para os contextos educacionais e acadêmicos, os gêneros discursivos se transformam em insumos que promovem a educação linguística.

No intuito de ampliar as possibilidades de trabalho com os gêneros discursivos, abordamo-los como catalisadores (SIGNORINI, 2006) de processos de reflexão crítica na formação de professores de línguas. Isso posto, o filme foi escolhido como um gênero em potencial, de modo que se investigou como ele poderia ser aplicado no contexto em questão a fim de estimular a reflexão crítica dos referidos profissionais. Para cumprir esse objetivo, elaboramos uma sequência didática (DOLZ; NOVERRRAZ; SCHNEWULY, 2004) para o gênero filme e a aplicamos em um curso temático intitulado Formação crítico-reflexiva de professores de línguas 
mediada por filmes sobre professores oferecido pelo Programa Permanente de Extensão UnB Idiomas (PPE UnB Idiomas) da Universidade de Brasília a um grupo de professoras de línguas. $O$ desenvolvimento desta pesquisa orientou-se pela metodologia pesquisa-ação (BARBIER, 2007) por esta se alinhar à perspectiva sociodiscursiva e dialógica de linguagem e por se interessar na problematização de questões que emergem de contextos como a sala de aula, convidando os participantes a se envolverem coletivamente na construção de sentidos diante da complexidade do real.

Esta pesquisa justifica-se pelo apontamento de autores como Napolitano (2006), de que o filme vem sendo utilizado em contextos educacionais apenas como mecanismo de fruição estética. Por isso, consideramos fundamental superar esse caráter com o propósito de elevar o filme à categoria de gênero que pode mediar exercícios de reflexão do sujeito diante de discursos construídos e projetados pela indústria cultural.

Quanto à organização deste artigo, inicialmente, apresentamos algumas considerações teóricas acerca da prática crítico-reflexiva na formação de professores de línguas, abordamos o filme como gênero discursivo a partir do dialogismo sociodiscursivo e em seguida, apresentamos uma proposta de sequência didática para a obra $O$ Substituto (Detachment, 2011) como uma estratégica de uso do filme em contextos de formação de professores de línguas. Logo, expomos a análise dos dados gerados por intermédio das reflexões suscitadas no curso temático e discutimos, em diálogo com os postulados advindos do referencial teórico, as reflexões críticas empreendidas pelas professoras participantes.

\section{A prática crítico-reflexiva na formação de professores de línguas}

Nos dias atuais, os contextos em que os professores estão inseridos têm imposto cada vez mais exigências a esses profissionais, de modo que se torna fundamental a construção de uma sólida formação para o exercício da docência não apenas pela aquisição de saberes, competências e 
metodologias, mas também pelo desenvolvimento de um habitus ${ }^{2}$ para o exercício da reflexão crítica.

Em relação à formação de professores de línguas, no âmbito brasileiro, são representativos os trabalhos de Liberali (2004), Magalhães (2004), Gil (2005), Moura Filho (2011), Vieira-Abrahão (2010, 2012), Silva (2013) e Gimenez (2013), os quais denominam a formação reflexiva de "prática crítico-reflexiva", pois consideram que o processo educativo, realizado pelo viés da criticidade, possibilita o desenvolvimento da cidadania e da emancipação ${ }^{3}$ do professor em formação inicial ou contínua. Embora pesquisadores como Gil $(2005$, p. 175) tenham refletido que, "através da reflexão pode haver modificações leves nas práticas dos professores, já que se comprova que a tradição cristalizada de práticas didáticas impõe sérios obstáculos para as mudanças”, a prática reflexiva tem conseguido se destacar na LA, visto que a reflexão configura-se como possibilidade de transformação.

Nesse cenário, o professor deixa de ser um mero consumidor de teorias e se transforma em indivíduo mais autônomo, que reflete sobre sua prática e a adequa aos contextos locais onde atua; o que significa produzir novas teorias a partir de suas experiências e necessidades (VIEIRAABRAHÃO, 2010).

A reflexão sobre a prática deve ser uma preocupação tanto dos professores em formação quanto dos formadores de professores, pois:

\section{[...] a aprendizagem docente como prática reflexiva é}

2 De acordo com Bourdieu (1972, p. 209), habitus consiste em esquemas mentais que o sujeito desenvolve ao longo da vida através da experiência e que lhe permite pensar, perceber, avaliar e agir frente a situações diversas.

3 Com base em Freire (1970/2013, 1996/2004) entendemos a emancipação como algo que faz com que os homens e mulheres ajam com o mundo em busca de sua transformação. Através de uma educação problematizadora e voltada para a prática da liberdade, a emancipação possibilita aos sujeitos oprimidos, os quais estão compreendidos dentro de um sistema socioeconômico que os impede de viver sua condição humana integralmente, tornarem-se mais autônomos e libertarem a si próprios e a seus opressores. No que tange à formação de professores, a emancipação está relacionada ao reconhecimento da profissão de professor por parte desses profissionais e da sociedade como mais autônoma e merecedora de confiança em relação à sua competência e à sua ética. 
fundamentada no pressuposto de que o professor aprende da experiência pessoal por meio da reflexão focalizada na natureza e no significado das experiências de ensino. É por meio do processo reflexivo sistematizado que o professor analisa e avalia seus objetivos, suas próprias ações em sala de aula, buscando compreender suas origens e consequências para o aluno, para a escola e para a sociedade como um todo. Por meio da reflexão busca-se o desenvolvimento profissional permanente (VIEIRAABRAHÃO, 2010. p. 228-229).

Portanto, em um sentido mais abrangente, formar professores de línguas na abordagem da prática crítico-reflexiva contribui para o desenvolvimento da autonomia da profissão, para o fortalecimento da identidade profissional e para a transformação da sociedade por meio de uma educação linguística emancipadora.

As bases da reflexão sobre a educação, principalmente a noção de ação reflexiva, que deram origem à figura do profissional reflexivo, podem ser encontradas em Dewey (1933). Em seguida, Schön (1983) "revitalizou e conceituou mais explicitamente a figura do profissional reflexivo ao propor uma epistemologia da prática, da reflexão e do conhecimento na ação" (PERRENOUD, 2002, p. 14). Na verdade, Schön (1983) contribuiu para uma abertura do paradigma do profissional reflexivo, associando-o à profissão de professor, bem como a outras, através de fecundos paralelismos.

De modo geral, consideramos que, para Dewey (1933), o ato de pensar é de fundamental importância para os seres humanos, porque é o que os tornam diferentes de outros seres vivos. Entretanto, o tipo de pensamento defendido pelo estudioso e que ele considera como a melhor maneira de o ser humano pensar não é um pensamento simples, mas sim aquele denominado de "pensamento reflexivo". Para que este seja posto em prática pelo indivíduo, é necessário examinar mentalmente o assunto ou a situação a fim de oferecer considerações sérias e consecutivas. Segundo Dewey (1933, p. 18):

[...] o pensamento reflexivo faz um ativo, prolongado e cuidadoso exame de toda crença ou espécie hipotética de conhecimento, exame efetuado à luz dos argumentos que a apoiam e das conclusões a que chega. [...] para firmar uma crença em sólida base de evidência e raciocínio, é necessário um esforço consciente e voluntário. (Grifos do autor.) 
Assim, pensar reflexivamente envolve a pesquisa sobre crenças, as quais têm influência direta no pensamento e nas ações das pessoas. Ao fazer isso, o sujeito é tomado por uma inquietação que o conduz a investigar minuciosamente aquilo que o perturba. Esse processo de reflexão não é uma sequência, mas uma consequência, visto que cada ideia consecutivamente ordenada engendra outra que remonta à sua antecessora. Desse modo, o pensar reflexivo é uma cadeia em que "há unidades definidas, ligadas entre si de tal arte que o resultado é um movimento continuado para um fim comum" (DEWEY, 1933, p. 14).

Tendo em vista que o ato reflexivo é fundamentalmente um ato intelectual, uma vez que ele encoraja o sujeito a um constante questionamento sobre o mundo, e que há sempre um objetivo a ser alcançado, podemos considerar que pensar reflexivamente é o que torna um educador responsável e intelectual. Isto é, o ato pedagógico do educador responsável o conduz à capacidade de refletir sobre sua prática e de se intelectualizar.

Mayrink (2007) faz algumas elucidações em relação às contribuições de Dewey (1933) e de Schön (1983) sobre a prática crítico-reflexiva na formação de professores. No caso de Dewey (1933), merece destaque a tese de que a reflexão pode ser desenvolvida e cultivada por meio da educação, e de que os hábitos de reflexão e de aprendizagem dependem da iniciativa dos sujeitos envolvidos no processo educativo. Nesse sentido, Mayrink (2007) considera que os professores podem aprender a refletir, de modo a tomarem consciência acerca da reflexão e das contribuições que esse processo pode desencadear. Entretanto, é imprescindível que haja um desejo real de concretizar o pensamento reflexivo. Schön (1983), por sua vez, sugere um modelo de reflexão que se ramifica em "reflexão na ação" (reflection in action) e "reflexão sobre a ação" (reflection on action). A primeira ocorre quando, pelo viés do nosso pensamento, reformulamos o que estamos fazendo durante o processo de elaboração. No caso do professor que atua na sala de aula, ambiente repleto de situações instáveis e conflituosas de ensinoaprendizagem, esse tipo de reflexão acontece quando ele precisa tomar decisões e resolver problemas no momento de sua atuação. A segunda, que se constitui como um processo deliberado e consciente, acontece depois da ação presente. $O$ professor a empreende ao pensar em sua aula e em como o 
conhecimento utilizado na ação em sala de aula pode ter contribuído para que ele conseguisse os resultados observados.

Há alguns trabalhos que fazem críticas a Schön (1983), entre os quais se pode mencionar Pimenta (2002), que percebe uma reflexão mais individual na proposta do autor, pois fica restrita à sala de aula e não atinge o contexto social, o qual também tem influência direta sobre a escola e suas unidades menores. Essa autora sugere possibilidades de se superarem os limites identificados na concepção de Schön. De maneira sintética, Moura Filho (2011, p. 54) assevera a respeito da contribuição de Pimenta (2002), enfatizando que ela "nos faz ver que é preciso que assumamos, de fato, que a profissionalização dos docentes, inclusive a dos de línguas estrangeiras, não pode se restringir à aquisição da competência linguística e ao domínio de aparatos metodológicos".

Pimenta (2002) organiza sua proposta de crítica ao construto de professor reflexivo, procurando investigar suas origens, seus pressupostos, seus fundamentos e suas características. Inicialmente a pesquisadora faz uma revisão desse conceito a partir das propostas de Schön (1983). A autora buscou, também, analisar a maneira pela qual esse construto foi apropriado generalizadamente no Brasil, criticar as bases políticas e ideológicas em confronto nas políticas de formação de professores, além de apontar a transformação do conceito, tendo em vista as diversas contradições observadas. A conclusão de Pimenta (2002) é a de que os professores devem superar a identidade meramente reflexiva para se assumirem como intelectuais críticos e reflexivos, o que contribuirá para se questionarem alguns equívocos acerca da maneira como a educação e a formação de professores ocorrem no Brasil.

Cumpre salientar que a prática reflexiva pode não ser suficiente para enfrentar a complexidade do real, mas ela é uma condição necessária (PERRENOUD, 2002), uma vez que a complexidade dos contextos de trabalho das profissões exige mais do que a aplicação de saberes acadêmicos. $\mathrm{Na}$ verdade, o profissional precisa saber articular criticamente os problemas que lhe são apresentados a fim de ter a capacidade de agir em situações complexas. Desse modo, tem-se a competência profissional (capacidade de gerenciar o desvio entre o trabalho prescrito e o trabalho real), a qual somente é possível por meio do desenvolvimento da autonomia, que está no cerne da profissionalização do professor. À medida que esse ofício adquire uma autonomia mais estatutária, com base na confiança que a sociedade tem em 
relação às suas competências e à sua ética, o professor passa a ser coletivamente reconhecido como um profissional.

Com o intuito de aprofundar a discussão sobre a reflexão crítica, Liberali (2004) defende que um trabalho reflexivo e crítico deve ter como base as quatro formas de ação discutidas por Freire (1970/2013) e por Bartlet (1990), a saber: a) descrever (relacionada à descrição da ação por meio de textos orais ou escritos, e procura responder às perguntas $O$ que faço? ou $O$ que fiz?); b) informar (referente à busca pelos princípios que embasam as ações, e tem questões como Qual o significado das minhas ações?); c) confrontar (relativa à indagação sobre as teorias formais que embasam as ações, e tem algumas perguntas políticas como Quem tem poder em minha sala de aula?); d) reconstruir (concernente à emancipação, e tem perguntas do tipo Como você organizaria essa aula de outra maneira? Por quê?). A prática crítico-reflexiva, desse modo, considera que o sujeito é capaz de se emancipar e de construir sua cidadania a partir da realização de confrontos ante diferentes contextos. Esse processo vale-se da cooperação entre os participantes, processo que ocorre por intermédio da linguagem. Na verdade, ele inicia-se com a descrição das ações, segue com a discussão das teorias que embasam essas ações, fortalece-se com a autocrítica e finaliza-se com a apresentação de uma proposta de reconstrução, ou seja, de mudança referente à ação.

A nossa concepção de prática crítico-reflexiva está relacionada à emancipação do professor por intermédio da participação em processos coletivos e colaborativos de formação. Mediante o uso da linguagem na escrita de diários e no engajamento em sessões reflexivas, torna-se possível ao docente analisar seu saber-fazer diante das situações verificadas na sala de aula e na escola. Dessa maneira, o professor exercita sua autocrítica, estabelece relações entre teoria e prática e apresenta propostas para a reconstrução das ações, contribuindo para o fortalecimento da autonomia da profissão. Nas situações de interação que objetivam promover movimentos de (trans)formação docente, o filme se apresenta como um gênero discursivo que pode mediar esse processo. 


\section{$3 \mathrm{O}$ filme como gênero discursivo mediador da formação de professores de línguas}

O filme, tomado como o resultado de uma esfera artística mais ampla que é o cinema, ao ser considerado como um signo, constitui a enunciação como um de seus elementos e, assim, demanda a existência de um interlocutor, ou seja, de um "outro" com o qual e para o qual se comunica algum enunciado. Segundo Rodrigues (2005), o enunciado é apenas um fragmento do discurso e, por isso, é único e não se repete a cada enunciação. Por ser de caráter tanto individual quanto social, a enunciação é capaz de provocar transformações nas formas internas da língua, tendo em vista que se manifesta sempre com objetivos e em contextos específicos (BAKHTIN, 1929/2004).

Conforme Bakhtin (1929/2004), a verdadeira substância da língua é o seu fenômeno social de interação verbal realizada por enunciados. Nessa perspectiva, as manifestações linguísticas que se materializam em formas de gêneros discursivos, a partir das funções que lhes são dadas e dos objetivos interacionais dos sujeitos, remetem a outros enunciados já ditos e previstos no e pelo discurso do outro. Na verdade, um enunciado traz consigo uma multiplicidade de vozes discursivas, além de ser determinado pelo seu projeto discursivo, o qual considera o autor e o seu querer dizer, bem como pela realização desse projeto a partir da vinculação da produção do enunciado às condições sociais de interação (RODRIGUES, 2005).

O papel do "outro" e dos signos é altamente significativo para o estabelecimento de relações entre os indivíduos, pois é por meio deles que os sujeitos tomam consciência de si, constroem e reconstroem suas identidades na e pela interação. Para Bakhtin/Voloshinov (1929/2004, p. 35), "os signos só podem aparecer em um terreno interindividual". Isso significa dizer que o aspecto ideológico contido nos signos somente é possível a partir do uso organizado que o homem faz deles em sociedade. Percebe-se que o fato de os indivíduos interagirem organizadamente é que permite a constituição ideológica do signo, este que inicialmente fazia parte apenas do mundo material, natural e/ou de consumo. O valor ideológico do signo implica também seu valor semiótico, visto que representa e refrata a realidade. Nesse sentido, todo signo é social por natureza, ou seja, até mesmo o signo da individualidade carrega consigo um caráter social, pois o 
pensamento do sujeito "desde a origem, pertence ao sistema ideológico e é subordinado a suas leis" (BAKHTIN/VOLOSHINOV, 1929/2004, p. 59).

Os signos utilizados pelos indivíduos para materializarem a língua são denominados por Bakhtin (2011) como gêneros do discurso, os quais integram as atividades humanas, isto é, como tipos relativamente estáveis de enunciados orais e escritos, que mantêm um conteúdo temático, uma estrutura composicional e características específicas. Tendo em vista essa definição de gêneros discursivos, é interessante relacioná-la às reflexões de Rodrigues (2005) a esse respeito. De acordo com essa pesquisadora, o fato de os gêneros discursivos serem formas de enunciados relativamente estáveis e normativas significa dizer que existe uma relação dialética entre os gêneros e os enunciados. Nessa perspectiva, Bakhtin "olha os gêneros a partir da sua historicidade (eles não são unidades convencionais) e lhes atribui a mesma natureza dos enunciados (natureza social, discursiva e dialógica), ao tomálos como seus tipos históricos" (RODRIGUES, 2005, p. 163). Portanto, ao analisarmos a evolução conceitual do termo "gênero discursivo", é possível observar que, enquanto os enunciados são individuais e únicos, os gêneros discursivos são impessoais, na medida em que existe neles uma linguagem concreta e histórica, a qual lhes confere certa estabilidade de traços. Entretanto, esta estabilidade dos gêneros discursivos não está em suas propriedades linguísticas formais, mas em sua relação com a situação social de interação.

Os gêneros existem em determinados campos nos quais eles são predominantes, ou até mesmo insubstituíveis. Embora alguns gêneros não possam ser substituídos, podemos dizer que eles se atualizam no sentido de que o surgimento de um novo gênero não implica o desaparecimento do anterior. Um exemplo é o fato de que os vídeos instantâneos produzidos nos aparelhos celulares e as transmissões ao vivo realizadas por qualquer pessoa nas redes sociais não significaram a inexistência de utilidade dos filmes idealizados por profissionais do cinema. Assim, nota-se que os gêneros discursivos têm um caráter de processo que está intimamente ligado à atividade humana, ou seja, as forças reguladoras próprias dos gêneros discursivos também contribuem para que, a cada situação de interação nova e específica, eles possam se renovar como forma de continuidade de sua própria existência na sociedade (RODRIGUES, 2005).

Com a evolução da sociedade, bem como das tecnologias, novas práticas sociais, como o cinema, foram inventadas pelo homem, a fim de 
transmitir seus anseios comunicacionais, no final do século XIX. Essa nova prática social foi possibilitada pelo desenvolvimento do gênero filme, o qual é constituído por uma multimodalidade discursiva que mescla imagens, sons, letras e cores. Podemos tomar o filme como um gênero que surgiu "nas condições da comunicação cultural 'mais complexa', no âmbito das ideologias formalizadas e especializadas, que uma vez constituídas, 'medeiam' as interações sociais: na esfera artística, científica, religiosa, jornalística, escolar etc.” (RODRIGUES, 2005, p. 169). Entretanto, a prática de fazer filmes tem extrapolado o âmbito formal, passando a estar presente no cotidiano das pessoas. É perceptível que hoje em dia os filmes assumiram diferentes formatos e funções na interação humana, de modo que a possibilidade de criação de um filme deixou de ser um privilégio dos cineastas, os quais detinham o conhecimento técnico sobre a produção cinematográfica.

Os filmes também foram sendo integrados a outras práticas e espaços sociais, como a sala de aula da educação básica e de formação de professores nas universidades. A esse respeito, é possível perceber algumas propostas de uso de filmes para mediar a aquisição de língua/cultura (CRUZ, 2004; GOMES, 2006; GARCIA DE STEFANI, 2010; SANTIAGO VIGATA, 2011; LIMA, 2012) ou para contribuir com a formação de professores de línguas (MAYRINK, 2007; GARCIA DE STEFANI, 2015). Em vista disso, podemos refletir que existe um processo dialético na relação entre o sujeito e os signos, já que "[...] cada época e cada grupo social têm seu repertório de formas de discurso na comunicação sócio-ideológica" (BAKHTIN, 1929/2004, p. 43). Essas formas são os signos, os quais resultam de um consenso entre os indivíduos no processo de interação.

Segundo Mayrink (2007), no que se refere ao gênero filme, é pertinente notar a distinção de aplicabilidade que se confere a ele em diferentes contextos e com diferentes funções. Essa pesquisadora, com base em Vygotsky (1978/2007; 1934/1999), demonstra a relevância dos sistemas simbólicos (signos e instrumentos) na relação que o sujeito estabelece com o mundo. Nesse sentido, entende-se que o filme se torna um instrumento quando é orientado externamente e serve apenas como um controlador da natureza, influenciando momentaneamente o espectador. Por outro lado, e de maneira mais adequada, o filme é um signo quando, por meio de sua linguagem cinematográfica (verbal e não verbal), “[...] pode contribuir, em um sentido amplo, para a construção do conhecimento do homem a respeito 
do mundo que o cerca" (MAYRINK, 2007, p. 43), agindo sobre o indivíduo mediante uma relação complexa e transformadora de estímulo, resposta e mediação.

Os filmes, ou seja, signos ideológicos, são pensados como artefatos culturais que, de uma maneira dialógica, conduzem o espectador a refletir sobre si e sobre a realidade exterior da qual faz parte. Consideramos essa possibilidade mediante as reflexões de Bakhtin/Voloshinov (1929/2004) sobre o fato de que o sujeito, constituído pela palavra, somente apreende a enunciação do outro ao estabelecer uma relação mental com o seu próprio discurso interior.

De posse dessa reflexão, entendemos que a prática de assistência a filmes na universidade constitui-se como um ato político motivador e provocador de discussões problematizadas entre aquilo que está representado no discurso cinematográfico e a realidade factual na qual os sujeitos espectadores (professores em formação) estão inseridos. A respeito dos filmes Mayrink (2007. p. 44-45) reverbera que:

[... ] se inseridos no contexto de formação de professores, torna-se possivel fazer um novo recorte dos filmes a fim de desencadear uma reflexão crítica sobre a prática pedagógica, atribuindo-lhes, então, uma nova função - a de signo - pois passa-se a fazer um uso consciente deles, orientado para determinado fim: a reflexão crítica sobre a prática pedagógica. $O$ ato de ver o filme vem acompanhado, então, de uma discussão que gera uma reflexão que pretende estender-se para além do entretenimento, do momento em que o espectador (o futuro professor) assiste ao filme. Tratase, portanto, de um efeito contínuo (e não situacional $e$ momentâneo) que se quer atingir com o filme, para que os futuros professores façam da reflexão crítica um componente permanente da sua prática diária como professores.

O cinema constrói e propaga, por meio dos filmes, ideologias, visões de mundo e representações identitárias capazes de provocar mudanças na sociedade. Assim, os filmes podem funcionar como meios de comunicação manipulados pelos aparelhos ideológicos de Estado 4 (ALTHUSSER, 1985),

4 Os aparelhos ideológicos de Estado são "um certo número de realidades que se apresentam ao observador imediato sob a forma de instituições distintas e 
com propósitos de alterar determinados acontecimentos, estruturas e padrões comportamentais dos indivíduos. Ao ser pensado dessa maneira, o filme passa a fazer parte dos gêneros discursivos secundários, os quais, conforme explica Rojo (2005, p. 197), estão relacionados "às esferas dos sistemas ideológicos constituídos, que surgem em situações sociais mais complexas e evoluídas, muitas vezes relacionadas complexamente à modalidade escrita da linguagem".

O filme é o resultado de diferentes estruturas semióticas, como a escrita do roteiro a partir do qual ele surge e outros elementos que possibilitam sua estética visual e musical. Ao ser constituído dessa forma, o filme e seus autores (inicialmente o roteirista e o diretor, mas também toda a equipe responsável por ele) esperam passar por uma apreciação valorativa de seus interlocutores (espectadores) acerca dos temas e discursos presentes na narrativa cinematográfica, que podem vir a ser aceitos, ignorados ou confrontados ideologicamente. O discurso presente no interior e no exterior do filme torna-se possível ante a relação dialética existente entre o gênero discursivo e a sua enunciação, ou seja, o seu contexto situacional. De acordo com Rojo (2005, p. 197):

[...] as relações entre os parceiros da enunciação não se dão num vácuo social. São estruturadas e determinadas pelas formas de organização e de distribuição dos lugares sociais nas diferentes instituições e situações sociais de produção dos discursos. É o que Bakhtin/Voloshinov designam por esferas comunicativas, divididas em dois grandes estratos: as esferas do cotidiano (familiares, íntimas, comunitárias etc.), onde circula a ideologia do cotidiano, $e$ as esferas dos sistemas ideológicos constituídos ( $d a$ moral social, da ciência, da arte, da religião, da política, da imprensa etc.). Em cada uma destas esferas comunicativas, os parceiros da enunciação podem ocupar determinados lugares sociais - e não outros - e estabelecer certas relações hierárquicas e interpessoais - e não outras; selecionar e abordar certos temas - e não outros; adotar certas finalidades ou intenções comunicativas - e não outras, a partir de apreciações valorativas sobre o tema e sobre a parceria.

especializadas", a saber: religioso, escolar, familiar, jurídico, político, sindical, de informação e cultural. Não devem ser confundidos com "Aparelho (repressivo) de Estado" (ALTHUSSER, 1985, p. 68). 
O cinema, por meio da circulação do seu produto - o filme -, atua sobre a sociedade por meio da representação de identidades marcadas por símbolos que variam de acordo com o contexto social, histórico e cultural. Retomando as reflexões de Rojo (2005), podemos dizer que o discurso enunciado pelo gênero discursivo filme é resultante de observações e pesquisas feitas pelos seus realizadores a respeito das regularidades e das similaridades existentes nas relações sociais dentro de uma esfera comunicativa específica. O fator social influencia diretamente os filmes a serem produzidos, de modo que o sujeito é interpelado a se posicionar diante dos discursos produzidos pela e na relação entre cultura e significado.

Portanto, considerando o potencial que os filmes apresentam de subjetivar seus espectadores, entendemos que seja fundamental inseri-los conscientemente na formação de professores a fim de dar a esses profissionais a oportunidade de refletirem criticamente sobre a sua prática pedagógica e sobre os discursos que permeiam os contextos educacionais. Para tanto, consideramos que as sequências didáticas sejam uma estratégia que possibilite transformar a assistência a filmes em uma experiência que ultrapassa os limites do entretenimento e da fruição estética, no sentido de provocar reflexões críticas. De posse das questões trazidas à baila até esta seção, a seguir, apresentamos uma proposta de sequência didática para $o$ gênero filme.

\subsection{Proposta de sequência didática para o filme $O$ Substituto (2011) aplicada à formação de professores de línguas}

Embora tenham se tornado amplamente conhecidas por orientar o trabalho com a Língua Portuguesa nas escolas, as sequências didáticas são um procedimento metodológico que pode ser usado para se ensinar qualquer conteúdo ou disciplina de maneira organizada em módulos.

Ao considerarmos que, segundo Dolz; Noverrraz e Schnewuly (2004. p. 82-83), "uma sequência didática é um conjunto de atividades escolares organizadas, de maneira sistemática, em torno de um gênero textual oral ou escrito", e com o intento de dar acesso "a práticas de linguagem novas ou dificilmente domináveis", tomamos o gênero filme e elaboramos uma proposta de sequência didática para que ele possa ser 
aplicado aos processos de formação de professores de línguas e consequentemente promova reflexões críticas.

Desse modo, buscamos ampliar as possibilidades de uso desse gênero para além da mediação dos processos de aquisição de línguas com o intuito de transformá-lo em um catalisador ${ }^{5}$ de reflexão crítica nos professores. Assim, a aquisição do gênero filme pelos professores não necessariamente significará que esses profissionais serão capazes de produzir o gênero, mas sim que terão adquirido competências para se valerem dele a fim de refletirem criticamente sobre si e sobre suas práticas docentes.

Nossa proposta de sequência didática para o filme $O$ Substituto (2011) foi organizada metodologicamente com base no modelo de Dolz; Noverraz e Schnewuly (2004, p. 83). Esses pesquisadores sugerem um esquema composto por apresentação da situação, produção inicial, trabalhos com os módulos e produção final. Essas etapas consistem, consecutivamente, na construção de uma representação do contexto de comunicação e da atividade de linguagem que será executada, na produção do gênero a partir de suas características específicas, na realização de várias atividades, a fim de se trabalhar os problemas decorrentes da primeira produção e superá-los; e na prática das noções e instrumentos adquiridos separadamente ao longo dos módulos. Caso fosse necessário retomar algum conteúdo ou competência que não foram aprendidos ou desenvolvidos, o mediador lançaria mão de estratégias para isso. De maneira a ilustrar, o esquema das sequências didáticas pode ser visualizado na Figura 1:

Figura 1. Esquema da sequência didática

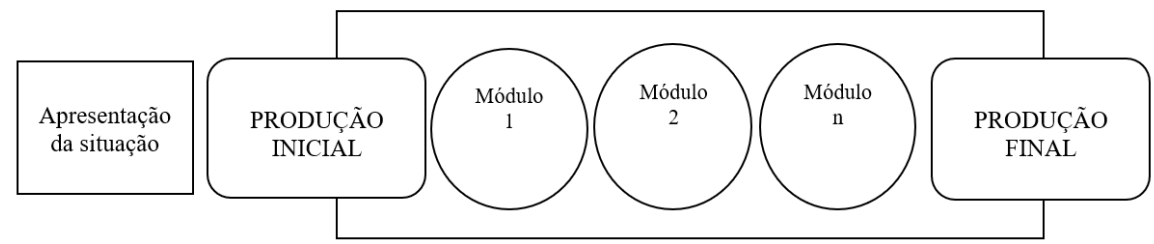

Fonte: Dolz, Noverraz e Schneuwly (2004, p. 83)

5 Segundo Signorini (2006, p. 8) “favorecem o desencadeamento e a potencialização de ações e atitudes consideradas mais produtivas para o processo de formação, tanto do professor, quanto de seus aprendizes". 
Considerando os objetivos desse trabalho, apresentamos, no Quadro 1, a sequência didática que elaboramos com o gênero filme a fim de se trabalhar a reflexão crítica em contextos de formação de professores de línguas.

\section{Metodologia e contexto de pesquisa}

As orientações metodológicas deste trabalho advêm da pesquisaação (BARBIER, 2007) e estão inseridas no paradigma qualitativointerpretativista, o qual tem ganhado cada vez mais espaço no campo da educação e da LA. Segundo Moita Lopes (1994), a pesquisa interpretativista pode contribuir de maneira mais reveladora, visto que não objetiva verificar hipóteses previamente estabelecidas, mas sim investigar como se dá o processo pelo qual o sujeito, usando a linguagem, significa e ressignifica o mundo por meio das relações sociais. Desse modo, na posição interpretativista, "não é possível ignorar a visão dos participantes do mundo social caso se pretenda investigá-lo, já que é esta que o determina: o mundo social é tomado como existindo na dependência do homem" (MOITA LOPES, 1994, p. 331). A pesquisa interpretativista considera mais relevante focar nos aspectos processuais e nas relações intersubjetivas, além de possibilitar o desenvolvimento de um mesmo objeto por diferentes visões e sem a neutralidade do pesquisador.

Entendemos que a pesquisa-ação coaduna com a perspectiva sociodiscursiva e dialógica (BAKHTIN/VOLOSHINOV, 1929/2004, FARACO, 2009), pois compreende que é por intermédio das práticas de linguagem que os participantes da pesquisa poderão realizar exercícios de reflexão crítica. 
O cinema como prática social...

Quadro 1. Sequência didática para o filme $O$ Substituto (2011)
Gênero: Filme
Suporte: Aparelho de Datashow, cópia do filme em DVD, textos impressos sobre a temática do filme e sobre a linguagem cinematográfica como montagem, planos, roteiro, som, fotografia.
Sugestão de documento: filme selecionado $O$ Substituto (Detachment, 2011).
Ações de linguagem exploradas: Análise fílmica, discussão oral e produção audiovisual.
Objetivos:
a. Discutir o gênero "filme";
b. Analisar os elementos de significação da linguagem cinematográfica;
c. Analisar o discurso do filme a partir de práticas dos letramentos midiático crítico $^{6}$ e visual ${ }^{7}$;
d. Realizar reflexão crítica e expressá-la oralmente;
e. Descrever e analisar as identidades da profissão "professor de línguas" no filme;

\section{Tempo estimado: 4 encontros.}

\section{Etapas da sequência:}

Atividade 1:

Apresentar às professoras o gênero a ser trabalhado: "filme". Mostrar a sinopse do filme e informar os aspectos (autor, duração, personagens principais). Explicar que o objetivo das atividades ao longo dos quatro encontros é refletir

6 Ferramenta que permite o sujeito ler o mundo de maneira mais crítica, no sentido de desenvolver uma compreensão mais global da sociedade e dos sistemas que a controlam (ALLRED, 2008).

7 Segundo Procópio e Souza (2009. p. 140-141), o termo consiste na "habilidade de entender e produzir mensagens visuais", percebendo a imagem visualmente, detalhadamente e criticamente. Essas pesquisadoras explicam que os indivíduos letrados visualmente estão aptos a "compreenderem os elementos básicos do design visual, perceberem as influências emocionais, psicológicas, fisiológicas e cognitivas nos visuais, compreenderem as imagens simbólicas, representacionais, explanatórias e abstratas". 


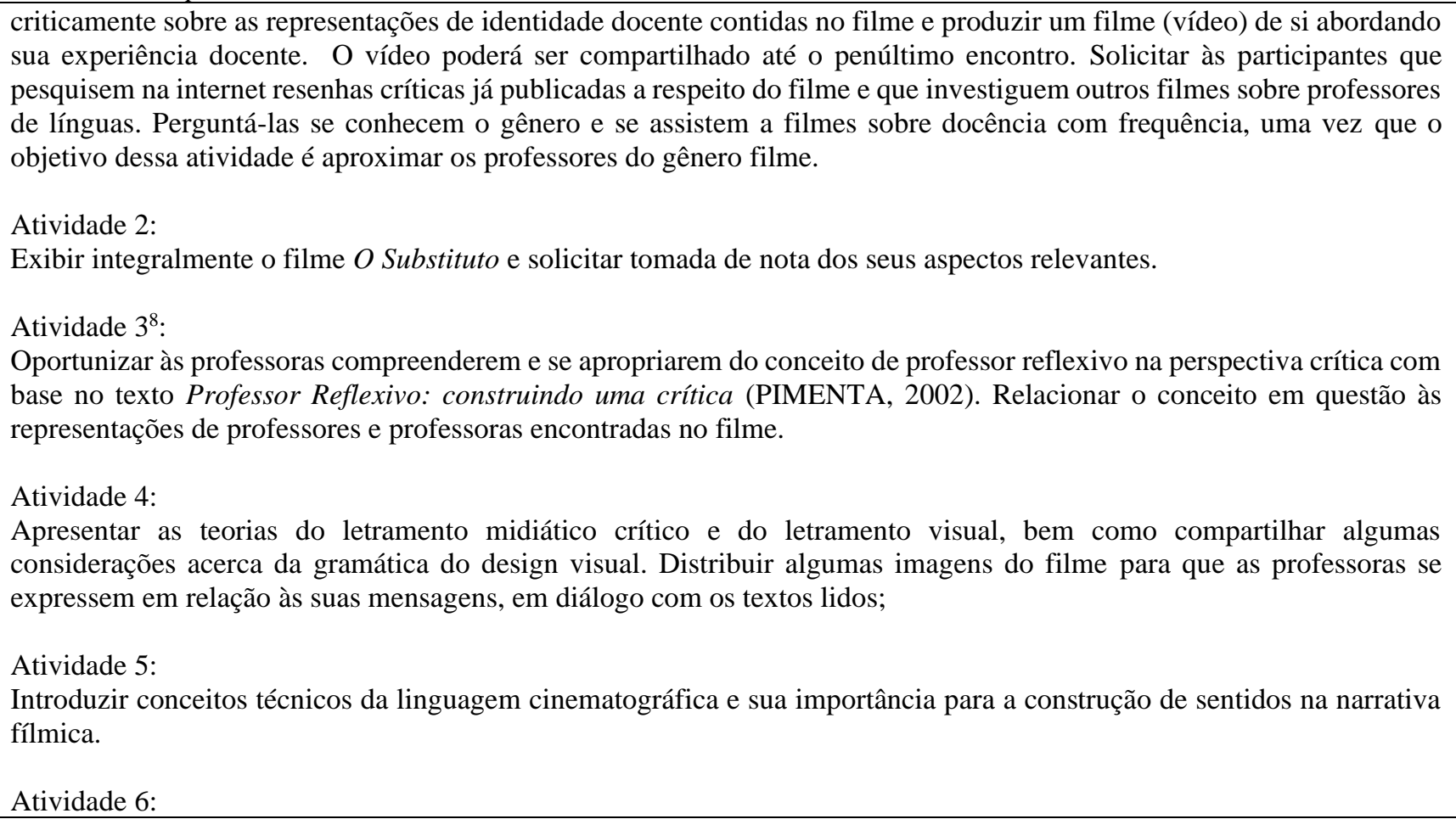

8 A descrição detalhada dessa atividade encontra-se no Anexo 1. 
Propor às participantes que confeccionem um vídeo (filme curta-metragem) representando as identidades de si em relação à profíssão "professor de línguas", bem como as concepções de língua/linguagem, ensino/aprendizagem de línguas.

Atividade 7:

Realizar uma Entrevista Focalizada ${ }^{9}$ (FLICK, 2009) sobre aspectos relevantes acerca da linguagem cinematográfica e das representações identitárias da profissão "professor de línguas". Pode-se fazer os questionamentos sugeridos pelo website: http://www.teachwithmovies.org.

Atividade 8:

Assistir aos vídeos produzidos e refletir coletivamente a seu respeito.

\section{Contexto de produção e uso:}

a. Realizar análises do discurso fílmico, bem como perceber a importância dos letramentos midiático crítico e visual na formação dos professores como possibilidade de empoderamento ante os discursos dominantes.

b. Estimular nos participantes a produção de vídeos como instrumentos de reflexão de si, dos outros e da identidade profissional.

Elementos linguístico-discursivos: imagens, cores, som, música, fotografia, montagem, falas dos personagens.

Reflexão pedagógica: O gênero discursivo multimodal "filme" pode ser aplicado à formação de professores de línguas como um instrumento a ser apropriado por eles no desenvolvimento dos letramentos midiático crítico e visual e como deflagrador da reflexão crítica. Nesse sentido, contribui-se para que o professor passe a refletir sobre as representações da profissão construídas pelo cinema e, consequentemente, possam ter novas compreensões da sua identidade profissional.

Atividades complementares: Produção de resenhas do filme visto.

Fonte: elaborado pelo primeiro autor

9 A entrevista focalizada encontra-se no Anexo 2. Trata-se de um instrumento que permite estudar o impacto que um estímulo uniforme (filme, etc.), tem sobre determinado grupo através da utilização de um guia de entrevista. 
Esta pesquisa foi realizada no contexto do Programa Permanente de Extensão UnB Idiomas (PPE UnB Idiomas) da Universidade de Brasília. Foi oferecido um curso temático intitulado Formação crítico-reflexiva de professores de línguas mediada por filmes sobre professores a um grupo composto por quatro professoras/estudantes de Letras. Com o intuito de alcançar os objetivos e responder às perguntas de pesquisa, as participantes assistiram a filmes ${ }^{10}$ que continham personagens professores de línguas em suas narrativas e refletiram criticamente sobre eles. Por questões de concisão textual, abordamos neste artigo apenas as considerações acerca do trabalho com o filme $O$ Substituto (Detachment, 2011), para o qual, como citado anteriormente, elaboramos uma sequência didática orientada pelo dialogismo sociodiscursivo de Bakhtin/Voloshinov (1929/2004) e pelas considerações de Dolz; Noverraz e Schneuwly (2004) sobre sequências didáticas para os gêneros orais e escritos.

Os registros foram coletados por meio de sete instrumentos. No entanto, neste artigo trataremos apenas dos registros das Gravações em Vídeo (GV) e da Entrevista Focalizada (EF) baseada em Flick (2009), os quais são resultantes das interações dos encontros quarto, quinto, sexto e sétimo da sequência didática. Apesar de um grupo maior de professoras ter participado, consideramos aqui apenas os relatos e impressões de Adeline (professora de francês) e de Catarina ${ }^{11}$ (professora de inglês).

No quarto encontro, o filme $O$ Substituto (2011) foi abordado como um gênero constituído por características específicas. No quinto encontro, a Atividade 3 foi desenvolvida, tomando o conceito de 'professor reflexivo' na perspectiva crítica defendida por Pimenta (2002), com o intuito de aprofundar o conceito de reflexão como um ato voltado para a prática social a partir de uma visão ampliada do contexto educacional. Procuramos também relacionar esse construto às representações de professores contidas no filme, enfocando o personagem central do filme, o professor de Inglês Henry Barthes, docente temporário em uma escola dos Estados Unidos. No sexto encontro, a discussão acerca do filme foi retomada e as professoras foram

10 Os filmes assistidos foram Sociedade dos Poetas Mortos (Dead Poets Society, 1989), Mentes Perigosas (Dangerous Minds, 1995), Bossa Nova (2000), Escritores da Liberdade (Freedom Writers, 2007), O Substituto (Detachment, 2011) e Adorável Professora (The English Teacher, 2013).

11 Pseudônimos escolhidos voluntariamente pelas professoras participantes. 
indagadas sobre suas concepções de 'professor reflexivo'. Foram realizadas também leituras de imagens do filme com base nas orientações dos letramentos midiático crítico e visual. Por fim, no sétimo encontro, aplicouse a EF para que as professoras respondessem aos questionamentos relativos às impressões desencadeadas pelas representações sobre a profissão de professor construídas pela narrativa fílmica. As participantes estabeleceram conexões entre o enredo do filme e suas relações pessoais e profissionais, sendo guiadas por exercícios de reflexão crítica, os quais são discutidos na próxima seção.

\section{As reflexões críticas realizadas pelas professoras mediante a aplicação da sequência didática}

Em face das discussões já realizadas e observando nosso propósito de investigar como o gênero 'filme' pode deflagrar reflexões críticas, na medida em que impacta seus espectadores, passamos a analisar alguns trechos do sexto e do sétimo encontros. Nesse contexto, é possível visualizar a maneira pela qual as professoras perceberam o filme $O$ Substituto (2011), orientadas pelas questões discutidas tanto na Atividade 3 , que objetivou a aplicação do conceito de professor crítico-reflexivo às representações sobre a docência presentes no filme, quanto na $\mathrm{EF}$, que buscou coletar as impressões das participantes sobre toda a narrativa fílmica apresentada. Observemos os Quadros 2 e 3, nos quais expomos as transcrições das interações das professoras. Ressaltamos que as características da linguagem oral e suas inconsistências gramaticais foram mantidas.

Conforme está explicitado no Quadro 2, percebemos que o filme estimulou o pensamento crítico das professoras por meio de processos de sensibilização orientados por questionamentos sobre o mundo (DEWEY, 1933) e pelos conceitos teóricos da prática crítico-reflexiva (LIBERALI, 2004; GIL, 2005) discutidos ao longo do curso temático. Na verdade, o filme constituiu-se como um instrumento que provocou nas participantes uma reação emotiva que evoluiu para um ato reflexivo, o qual possibilitou o início do processo de transformação e consequente emancipação (FREIRE, 1970/2013). Isso fica explicitado nas declarações das professoras Catarina: "Ele estimulou porque eu fiquei chocada com o filme (...) ele me chocou demais" e Adeline: "Eu saí deprimida daqui. O filme é muito pesado (...) fiz uma reflexão, pensei e fiz uma comparação”. 
Quadro 2. Dados coletados por intermédio das gravações em vídeo

\section{Transcrição do sexto encontro}

Pesquisador: (...) Em nosso curso o filme tem sido tomado como um gênero multimodal que por estar sendo aplicado à formação de professores pode funcionar como um instrumento deflagrador da prática crítico-reflexiva. Você concorda que o filme O Substituto estimulou a sua reflexão crítica? Por quê? De que maneira?

Catarina: Ele estimulou porque eu fiquei chocada com o filme. (...) Ai, ele me chocou demais aquele filme por vários motivos. A maneira que foi, que você tem que ver de uma forma muito mais ampla, o que acontece na vida das pessoas, dos seus alunos.

Pesquisador: E pra você acrescentou o que? Ou não acrescentou nada?

Catarina: Acrescentou que você tem que prestar atenção no seu papel, que não é só você chegar, dar aula, pegar sua bolsa e sair (...)

Pesquisador: Você concorda então que o filme ele realmente contribui pra que você como professora, seja vendo o filme lá na sua casa, você reflete sobre si, sobre sua práxis?

\section{Catarina: Sim.}

Pesquisador: Sobre sua identidade de professora?

Catarina: Sim.

Pesquisador: Adeline.

Adeline: Quando eu vi o filme eu saí antes do final. Eu saí deprimida daqui. O filme é muito pesado, são várias reflexões, várias observações. (...) fiz uma reflexão, pensei e fiz uma comparação. (...). E também me fez pensar também, que tá uma situação crítica, tá difícil, mas tem lá a parte do filme que tem a reunião dos pais, ninguém mais vai e eles estão "Ah, lembra, quando os pais vinham?" "Ficava lotado, faziam filas". Você fala: "Ah, é verdade. Mudou". Minha reflexão é: Aí tá, mas o que a gente pode mudar?

Pesquisador: É verdade. E ele tinha tantos problemas que eu acho também que a vida pessoal dele acabou refletindo na prática dele na escola.

Adeline: Exatamente. (...) Então, ao mesmo tempo que ele é um professor reflexivo ele também às vezes vai pro caminho mais fácil. Mas aí depois ele mesmo aprendeu com a escola e levou pra vida dele pessoal.

Pesquisador: Eu penso que até então ele não havia passado por uma escola que, tão pesada e que iria transformá-lo tanto. Eu acho que aquela escola realmente o transformou.

Adeline: Sim. Por exemplo. Aí eu pensando né. (...) Mas eu também percebo que a gente tá muito acostumado a sempre fazer a mesma coisa. Uma aula, tem que ler o livro e fazer uma apresentação do livro. (...). Então eu acho que é bom a gente modificar. 
Vale considerar que o verbo "chocar" e o adjetivo "deprimida" estão diretamente ligados ao emocional do indivíduo e que as professoras, enquanto espectadoras do filme, não precisaram se esforçar para se sentirem envolvidas por ele, pois esse é um efeito próprio do cinema. Para Catarina, os motivos desse "choque" referem-se ao fato de o filme ter lhe possibilitado visualizar melhor como a vida de alguns professores refletem na sala de aula e na vida dos alunos, uma vez que, de acordo com ela, "você tem que ver de uma forma muito mais ampla, o que acontece na vida das pessoas, dos seus alunos". Essas reflexões remontam ao que aborda Vieira-Abrahão (2010) ao argumentar que a prática crítico-reflexiva oferece ao professor a oportunidade de aprender a partir de sua experiência pessoal por intermédio de um ato reflexivo focalizado no sentido das experiências de ensino.

Ainda segundo essa pesquisadora, o professor faz uma avaliação dos seus objetivos e das suas ações em sala de aula, com o intuito de compreender quais serão as consequências para o aluno. Com esse propósito, é necessário pensar de maneira mais ampla acerca dos aspectos que interferem no processo de ensino e aprendizagem. A reflexão apresenta-se como uma ação mais coletiva que extrapola os espaços educacionais (PIMENTA, 2002), atingindo o contexto social, o qual influencia diretamente a escola e suas unidades menores. Ao expressar que o filme "Acrescentou que você tem que prestar atenção no seu papel, que não é só chegar, dar aula, pegar sua bolsa e sair", a professora Catarina demonstra que está se desenvolvendo como indivíduo autônomo que, conforme explica Vieira-Abrahão (2010), reflete acerca da realidade de sua prática profissional, adequando-se ao seu contexto de atuação e produzindo novas teorias com base nas necessidades que se apresentarem.

A possibilidade de o filme, por meio das representações, conduzir o espectador a uma nova percepção da sua realidade, evidencia-se na fala de Adeline, que emprega uma gama de palavras e enunciados relacionados ao pensamento: "reflexões", "pensei”, "fiz uma comparação”, "me fez pensar”, "minha reflexão”, "aí eu pensando" e "percebo”. Após realizar essas ações iniciais que a permitiram tomar consciência acerca das contribuições da reflexão crítica (MAYRINK, 2007) e estabelecer relações associativas com os aspectos que interferiam em sua prática docente, a professora se questiona: “Aí tá, mas o que a gente pode mudar?”. Esses processos referem-se respectivamente às ações de confrontar e de reconstruir sugeridas por Liberali (2004) com base em Freire (1970/2013), essenciais ao 
trabalho de agência por parte de professores que buscam encaminhamentos para os problemas manifestados no contexto escolar, sejam eles concernentes ao planejamento/execução das aulas, sejam relativos aos resultados do processo de ensino e aprendizagem. Percebe, portanto, conforme apontam Pimenta (2002) e Perrenoud (2002), que a prática crítico-reflexiva funcionou como mecanismo de enfrentamento da complexidade encontrada nos contextos de atuação das professoras, o que contribui para que elas sejam elevadas ao patamar de profissionais intelectuais que não apenas aplicam saberes linguísticos, por exemplo, mas que também gerenciam os desvios entre aquilo que está prescrito e o trabalho real.

Considerando que Adeline ainda se encontrava na formação inicial, as reflexões externadas remontam à sua experiência como aluna da graduação em Letras, de modo que foram feitas críticas aos procedimentos e às ações adotadas por alguns formadores de professores. Adeline salienta que havia se acostumado à maneira como as aulas que tinha na universidade eram conduzidas: "Mas eu também percebo que a gente tá muito acostumado a sempre fazer a mesma coisa. Uma aula, tem que ler o livro e fazer uma apresentação do livro”. Essas ações verbais nos remetem ao fato de que os espectadores, em contextos específicos, constroem o sentido do filme em diálogo com o mundo. Quando os sujeitos são ativos e críticos, o impacto que as representações da narrativa cinematográfica desencadeiam lhes possibilitam refletir criticamente e encontrar respostas diante da realidade (PERRENOUD, 2002).

Passamos agora a explorar um pouco mais o reflexo do filme sobre as professoras, por meio da análise de suas respostas durante a aplicação da EF, que, de acordo com Flick (2009, p. 144), é utilizada no sentido de que, "após a apresentação de um estímulo uniforme (um filme, uma transmissão por rádio, etc.), estuda-se o impacto deste sobre o entrevistado a partir da utilização de um guia de entrevista". Ressaltamos que a diferença das respostas dadas pelas professoras nesta etapa da pesquisa e outras coletadas em momentos anteriores refere-se ao fato de que, em certa medida, as discussões foram controladas, utilizando um guia com perguntas específicas previamente elaboradas. Consideremos a interação decorrente da EF no Quadro 3. 
Quadro 3. Dados coletados por intermédio da entrevista focalizada

\section{Transcrição do sexto encontro}

Pesquisador: O que mais impressionou vocês nesse filme?

Adeline: São vários fatos. Várias áreas. Eu acho que é impressionante. O que realmente tá acontecendo. Os professores. Nós somos professores. O que eles estão fazendo pra entrar numa (...). Um toma remédio, o outro não consegue. $\mathrm{O}$ outro só leva com a barriga vai, não faz. O outro já tenta modificar.

Pesquisador: Assim, a gente falava muito em crise né. Crise de identidade profissional.

Adeline: Crise. A crise. E eu acho que também reflete não só na escola, mas a sociedade. Porque a escola é pra te preparar pra sociedade. Ela te prepara pra conviver com outros. Eu acho que se a escola está assim, não é só a escola, a consequência é da sociedade. Por que eles aprendem?

Pesquisador: Catarina, o que mais impressionou você no filme?

Catarina: A inversão de valores.

Pesquisador: Inversão de valores em que sentido? Como assim?

Catarina: A escola como instituição, os pais. Aquela hora que a mãe xinga a psicóloga de puta. "Como assim gente?"

Pesquisador: Cospe nela eu acho. Não. Não é na psicóloga. É na professora ruiva.

Catarina: Como assim?

Pesquisador: E isso acontece. Já vi jogar cadeira na professora.

Catarina: Até que ponto chegou pra se estabelecer o caos. Por que não teve uma medida preventiva? Porque a gente vê que quando ele chega ali o caos já tá estabelecido há muito tempo. Você reflete por aquele professor que não consegue dá aula, isso é mostrado no professor que bebe remédio, na psicóloga que chega uma hora que fala que não aguenta mais. Então assim, aquilo ali já é um problema meio crônico né.

Adeline: E é tipo um "wake-up". "Tá acontecendo isso e aí?" "você vai ficar sentado aí, acabou de ver o filme e vai continuar assim?" (...)

Fonte: registros do primeiro autor

A situação exposta no Quadro 3 representa o efeito que o filme teve sobre as professoras. As respostas dadas por elas indicam que, no momento da contemplação da obra de arte, o sujeito empreende concomitantemente ações ligadas à razão e à paixão, à alienação e à desalienação, de modo que a passagem de um estado a outro pode ocorrer diversas vezes diante do espetáculo. Ao verbalizar que "vários fatos" mostrados no filme a impressionou e, em seguida, dizer que estava impressionada com " $O$ que realmente tá acontecendo”, a professora Adeline exercitou a reflexão, 
acionando eventos que estavam acontecendo no contexto em que estava inserida, ou seja, ao mesmo tempo em que ela estava emocionada com o filme, este também proporcionou a construção de um conhecimento a partir da reflexão a respeito do mundo real (MAYRINK, 2007).

A professora Catarina, por sua vez, observou a "inversão de valores”, que não somente a escola, mas também a sociedade como um todo, tanto no filme quanto na realidade, tem passado. Na verdade, há um estado de caos, no qual não há mais o respeito pelos pais nem pelos professores. Em certa medida, para ela, esse é um problema crônico e os docentes muitas vezes estão fadados a enfrentá-lo diariamente. Na sequência, a professora Adeline fez uma consideração bastante pertinente sobre o que realmente o filme quis provocar no espectador. Segundo ela: "E é tipo um "wake-up." "Tá acontecendo isso e aí?" "você vai ficar sentado aí, acabou de ver o filme e vai continuar assim?” - Adeline. Essas proposições indicam que, ao assistirem ao filme, os sujeitos estabelecem uma relação dialógica com esse artefato cultural, de modo que um processo de fruição estética é empreendido concomitantemente a um movimento de transformação de discursos previamente existentes. Assim, a possibilidade de o filme mediar as relações dos indivíduos é o que respalda a nossa argumentação de que ele é um gênero discursivo em potencial (BAKHTIN, 2011), o qual, conforme os relatos da professora Adeline, a impulsionou para um processo de reflexão sobre a importância de os docentes participarem ativamente de práticas de linguagem como os debates que interessam às suas comunidades de prática.

$\mathrm{Na}$ sequência da EF, a professora Catarina foi perguntada sobre como se sentiu em relação à sequência introdutória do filme, que mostra cenas em preto e branco com depoimentos de professores narrando suas trajetórias na docência. A esse questionamento, foram apresentadas as seguintes considerações:

\section{Excerto 1.}

Catarina (EF): "Desvalorizada. Porque não é assim. Eu busco qualificação pra profissão e ser professor não é fácil, não é qualquer um. E ai essa sequência agora. "Ai, eu nunca quis ser professora"; "Minha mãe era professora e o que eu queria na vida era ser professora"; "Ah, eu queria ser professora"; "Ah, eu fui trabalhar e teve um furacão e eu vi que era muito fácil ser professor porque eu tinha alguns "off-days", né". Então assim, "Ah, não vou fazer nada, vou ser professor". E não é assim!" 
Percebemos, portanto, que a professora Catarina, ao dizer que se sentiu desvalorizada, estava fazendo referência ao fato de que há algumas pessoas que desempenham a profissão sem se identificarem com suas representações, além de apresentarem algumas deficiências na formação. Isto é, parece haver certa facilidade em se exercer o "ofício" de professor e, por isso, indivíduos que estão desmotivados profissionalmente ou que buscam se desviar de trabalhos mais exigentes e densos veem na profissão docente, na possibilidade de "dar aula", uma oportunidade de desempenhar uma vida profissional mais tranquila. Como resultado dessas concepções limitadas, muitos professores que buscam se profissionalizar, investindo em sua formação continuada, são afetados pelo desprestígio e pela desvalorização da profissão.

Nesse sentido, segundo a professora Catarina, a profissão docente é afetada não apenas pela carência de investimentos na educação e a consequente oferta de salários pouco atraentes, mas também "por questões de as pessoas acharem que é pequeno sabe, que "Ah, nada deu certo vai ser professor", "Ah, pra ser professor não precisa estudar". Professor infelizmente na sociedade não é visto (...)” - Catarina. A desvalorização, na concepção de Catarina, está relacionada com o discurso do outro sobre a profissão, de modo que isso culmina na desvalorização dos colegas entre si. Assim, muitos professores sentem-se vencidos e desistem de continuarem se ressignificando em favor de um fortalecimento profissional, pois, apesar de todo o esforço, sabem que continuarão sendo vistos como possuidores de um status inferior. Entretanto, embora Catarina se sentisse desvalorizada, o fato de ter participado do nosso curso temático indica um processo de mudança e de emancipação (FREIRE, 1970/2013) diante dos discursos de opressão que nela haviam se instaurado.

A representação de professor substituto exercida pelo personagem Henry Barthes fez com que a professora Catarina expressasse suas emoções. De acordo com ela, por um lado, sentiu-se bem "porque ele levou o pensamento pros alunos, ele conseguiu levar uma forma de pensar diferente" e, por outro, ficou "chateada, porque ele nunca dá continuidade ao que ele começou." Em vista disso, a professora Catarina acrescentou que não se sentiu representada pelo professor Henry Barthes, salientando que ser professor substituto significaria não ter a oportunidade de acompanhar os resultados do processo de ensino e aprendizagem de seus alunos. Entretanto, 
sabemos que, muitas vezes, por falta de oportunidades de trabalho, o professor termina se submetendo a desempenhar um papel de substituto contra sua vontade. Além dessas reflexões, o filme trouxe as seguintes contribuições à professora Catarina:

\section{Excerto 2.}

Catarina (EF): "Ele mostrou que não é só a sala de aula. O filme mostrou que não é só o âmbito da sala de aula, ele transpassa aquilo. Então assim, problemas meus, problemas de alunos, problemas de pais de alunos. Então, que a sua vida dentro da sala não reflete só ali, ela reflete em tudo."

Esse excerto demonstra que o filme possibilitou à professora compreender, de maneira ampla, a complexidade da escola, dos alunos, dos outros professores e também do contexto mais individual em que estão inseridos. Podemos inferir que a professora Catarina deixou de ver alguns problemas que envolvem a educação como coisas isoladas e desconectadas, passando a concebê-las de maneira interrelacionada. Por exemplo, tomando o que é mostrado no filme, se a vida do professor não estiver equilibrada em seus diferentes âmbitos, por algum motivo, é provável que suas aulas, bem como suas relações interpessoais, sejam afetadas negativamente.

Mesmo assim, o professor pode ressignificar sua prática diante das adversidades conforme ocorreu na sessão de visionamento do filme com a professora Catarina que ampliou sua visão sobre a docência. Na verdade, ao ser perguntada sobre qual representação ela tinha da profissão docente, respondeu: "Comprometimento com o que você tá fazendo, com o que você tá lecionando." Essa colocação dialoga com os postulados de Pimenta (2002) a respeito da importância da autonomia para que o professor se assuma como profissional e em vista disso seja reconhecido pela sociedade como um sujeito responsável e ético em sua plenitude, pois reflete criticamente sobre como suas ações irão impactar na formação de outros indivíduos. 


\section{Considerações finais}

Neste trabalho, abordamos o filme como um recurso pedagógico que tem sido amplamente utilizado em contextos escolares de ensino e aprendizagem de várias disciplinas e em contextos acadêmicos de formação de professores em geral. Em vista disso, considerando especificamente as salas de aula de formação de professores de línguas, elegemos o filme como um gênero discursivo em potencial e indagamos como ele poderia ser aplicado à formação desses profissionais com o propósito de estimular sua reflexão crítica. A partir dessa problemática, tecemos algumas considerações teóricas sobre a importância da prática crítico-reflexiva na formação de professores de línguas e sobre a constituição do filme como gênero discursivo. Em seguida, orientados pelos estudos referentes às sequências didáticas, elaboramos e aplicamos uma proposta para o filme $O$ Substituto (2011), a fim de cumprirmos os objetivos da investigação. Mediante a oferta de um curso temático orientado pela metodologia pesquisa-ação a um grupo de professoras de línguas, foi possível observar nas reflexões provenientes das interações entre as participantes, alguns movimentos de reflexão crítica e de transformação docente proporcionados pelo trabalho com o gênero filme a partir da abordagem das sequências didáticas.

Constatamos, com base na análise dos dados, que a proposta da sequência didática ofereceu encaminhamentos significativos para o planejamento do trabalho com filmes na formação de professores de línguas, visto que possibilitou às professoras participantes conhecerem o gênero filme e as suas características constitutivas, bem como refletirem criticamente sobre as representações profissionais de docentes contidas em suas narrativas. Salientamos que o filme, ao ser aplicado aos cursos de formação de professores de línguas por intermédio das sequências didáticas, supera objetivos unicamente estéticos e passa a funcionar como insumo para as práticas sociais de linguagem

\section{Referências}

ALLRED, C. Critical media literacy: a 21st century teaching tool. In: GIL, G.; VIEIRA-ABRAHÃO, M. H. Educação de professores de línguas: os desafios do formador. Campinas: SP: Pontes Editores, 2008. p. 91-104. 
ALTHUSSER, Louis. Aparelhos ideológicos de Estado: nota sobre os aparelhos ideológicos de Estado. Trad. Walter José Evangelista e Maria Laura Viveiros de Castro. 2. ed. Rio de Janeiro: Edições Graal, 1985.

BAKHTIN, Mikhail; VOLOCHINOV, Valentin. N. Marxismo e filosofia da linguagem. 11. ed. São Paulo: SP: Hucitec, [1929]2004.

BAKHTIN, Mikhail. Estética da criação verbal. 4. ed. São Paulo: Martins Fontes, 2011.

BARBIER, Rene. A pesquisa-ação. Brasília: Liberlivro, 2007.

BARTLET, Leo. Teacher development through reflective teaching. In: RICHARDS, J. C.; NUNAN, D. (orgs.). Second language teacher education. Cambridge: Cambridge University Press, 1990.

BOURDIEU, Pierre. Esquisse d'une théorie de la pratique. Genève, Droz, 1972.

CRUZ, Décio Torres Cruz. O cinema como linguagem pedagógica/ideológica para o ensino de línguas estrangeiras: (re)descobrindo a cultura do outro. In: MOTA, Kátia; SCHEYERL, Denise. (Orgs.). Recortes interculturais na sala de aula de línguas estrangeiras. Salvador: EDUFBA: Instituto de Letras, Departamento de Letras Germânicas, 2004. p. 143-172.

DEWEY, John. How we think. D.C. Heath and Company, 1933.

DOLZ, Joaquim; NOVERRAZ, Michèle; SCHNEUWLY, Bernard. Sequências didáticas para o oral e a escrita: apresentação de um procedimento. In: SCHNEUWLY, Bernard; DOLZ, Joaquim. Gêneros orais e escritos na escola. Tradução e organização de Roxane Rojo e Glaís Sales Cordeiro. Campinas, SP: Mercado de Letras, 2004. p. 81-108. (Coleção As Faces da Linguística Aplicada). 
FARACO, Carlos Alberto. Linguagem \& Diálogo: as ideias linguísticas do círculo de Bakhtin. São Paulo: Parábola Editorial, 2009.

FLICK, Uwe. Introdução à pesquisa qualitativa. 3. ed. Porto Alegre: Artmed, 2009.

FREIRE, Paulo. Pedagogia do oprimido. 47. ed. Rio de Janeiro: Paz e Terra, 1970/2013.

FREIRE, Paulo. Pedagogia da autonomia: saberes necessários à prática educativa. São Paulo: Paz e Terra, 1996/2004.

GARCIA DE STEFANI, Viviane Cristina. O cinema na aula de língua estrangeira: uma proposta didático-pedagógica para o ensino-aprendizagem de espanhol. 2010. 238p. Dissertação (Mestrado em Linguística) - Centro de Educação e Ciências Humanas, Universidade Federal de São Carlos, São Carlos, 2010. Disponível em: <https://repositorio.ufscar.br/handle/ufscar/5693?show=full>. Acesso em: 29 abr. 2020.

GARCIA DE STEFANI, Viviane Cristina. Formação continuada de professores de línguas estrangeiras mediada pelo cinema: contribuições da teoria da atividade. 2015. 284p. Tese (Doutorado em Linguística) Centro de Educação e Ciências Humanas, Universidade Federal de São Carlos, São Carlos, 2015. Disponível em: <https://repositorio.ufscar.br/handle/ufscar/7567> . Acesso em: 29 abr. 2020.

GIL, Gloria. Mapeando os estudos de formação de professores de línguas no Brasil. In: FREIRE, M. M.; VIEIRA-ABRAHÃO, M. H.; BARCELOS, A. M. F. Linguística Aplicada e contemporaneidade. São Paulo, SP: ALAB; Campinas, SP: Pontes Editores, 2005. p. 173-182.

GIMENEZ, Telma. Formação de professores de línguas no Brasil: avanços e desafios. In: SANTOS, L. I. S.; SILVA, K. A. da. Linguagem, ciência e ensino: desafios regionais e globais. Campinas, SP: Pontes Editores, 2013. 
GOMES, Francisco Wellington Borges. O uso de filmes legendados como ferramenta para o desenvolvimento da proficiência oral de aprendizes de Língua Inglesa. 2006. 132p. Dissertação (Mestrado em Linguística Aplicada) - Programa de Pós-Graduação em Linguística Aplicada, Centro de Humanidades, Universidade Estadual do Ceará, Fortaleza, 2006. Disponível em: <http://www.uece.br/posla/download/dissertacoes/>. Acesso em: 29 abr. 2020.

LIBERALI, Fernanda Coelho. As linguagens das reflexões. In: MAGAlHÃES, M. C. C. (Org.). A formação do professor como um profissional crítico: Linguagem e reflexão. Campinas, SP: Mercado de Letras, 2004.

LIMA, Luciano Rodrigues. Movies and cartoons in the EFL classroom: for a critical cultural immersion. In: LIMA, Diógenes Cândido. Language and its cultural substrate: perspectives for a globalized world. Campinas, SP: Pontes Editores, 2012. V. 21, p. 173-191. (Coleção Novas Perspectivas em Linguística Aplicada).

MAGALHÃES, M. C. C. (Org.). A formação do professor como um profissional crítico: linguagem e reflexão. Campinas, SP: Mercado de Letras, 2004.

MAYRINK, Mônica Ferreira. Luzes... Câmera... Reflexão: Formação inicial de professores mediada por filmes. 2007. 286p. Tese (Doutorado em Linguística Aplicada e Estudos da Linguagem) - Programa de Estudos PósGraduados em Linguística Aplicada e Estudos da Linguagem, Pontifícia Universidade Católica de São Paulo, São Paulo, 2007. Disponível em: <https://tede2.pucsp.br/handle/handle/13837>. Acesso em: 29 abr. 2020.

MOITA LOPES, Luiz Paulo da. (1994) Pesquisa interpretativista em Lingüística Aplicada: a linguagem como condição e solução. D.E.L.T.A.,v. 10, n. 2, . p. 329-338, 1994. Disponível em: <https://revistas.pucsp.br/delta/article/view/45412>. Acesso em: 29 abr. 2020. 
MOURA FILHO, Augusto Cesar Luitgards. A. C. L. Basta de clamarmos inocência: a formação reflexiva do professor contemporâneo de línguas. In: In: SILVA, Kléber Aparecido da. et al. (Orgs.). A formação de professores de línguas: novos olhares. Campinas, SP: Pontes Editores, 2011. V. 1, p. 4972 .

NAPOLITANO, Marcos. Como usar o cinema na sala de aula. 4. ed. São Paulo: Contexto, 2006.

PEREIRA, Lauro Sérgio Machado. O professor de línguas vai ao cinema: ressignificando a identidade profissional sob a perspectiva da formação crítico-reflexiva. 2014, 228p. Dissertação (Mestrado em Linguística Aplicada) - Instituto de Letras, Universidade de Brasília. Brasília, 2014. Disponível em: <https://repositorio.unb.br/handle/10482/17969>. Acesso em: 29 abr. 2020.

PERRENOUD, Philippe. A prática reflexiva no ofício de professor: profissionalização e razão pedagógica. Porto Alegre: Artmed, 2002.

PIMENTA, Selma Garrido. Professor reflexivo: construindo uma crítica. In: PIMENTA, Selma Garrido; GHEDIN, Evandro. (Orgs.). Professor reflexivo no Brasil: gênese e crítica de um conceito. São Paulo: Cortez, 2002. p. 17-52.

PROCÓPIO, Renata Bittencourt; SOUZA, Patrícia Nora de. Os recursos visuais no ensino-aprendizagem de vocabulário em língua estrangeira. Acta Scientiarum Language and Culture. Maringá, v. 31, n. 2. p. 139-146, 2009.

Disponível em: <http://periodicos.uem.br/ojs/index.php/ActaSciLangCult/article/view/8421 $>$. Acesso em: 29 abr. 2020.

RODRIGUES, Rosângela Hammes. Os gêneros do discurso na perspectiva dialógica da linguagem: a abordagem de Bakhtin. In: MEURER, José Luiz; BONINI, Adair; MOTTA-ROTH, Désirée. (orgs.). Gêneros: teorias, métodos, debates. São Paulo: Parábola Editorial, 2005. p. 152-183. 
ROJO, Roxane. Gêneros do discurso e gêneros textuais: questões teóricas e aplicadas. In: MEURER, José Luiz; BONINI, Adair; MOTTA-ROTH, Désirée. (orgs.). Gêneros: teorias, métodos, debates. São Paulo: Parábola Editorial, 2005. p. 184-207.

SANTIAGO VIGATA, Helena. Linguacultura em foco: material audiovisual legendado como mecanismo para o ensino intercultural de espanhol para brasileiros. 2011. 224p. Dissertação (Mestrado em Linguística Aplicada) - Instituto de Letras, Universidade de Brasília. Brasília, 2011. Disponível em: <https://repositorio.unb.br/handle/10482/18547>. Acesso em: 29 abr. 2020.

SCHÖN, Donald. A. The reflective practitioner. Nova York: Basic Books, 1983.

SIGNORINI, Inês. Prefácio. In: PENTEADO, Ana Elisa de Arruda [et al.]. Gêneros catalisadores: letramento e formação do professor. São Paulo: Parábola Editorial, 2006. p. 7-16.

SILVA, Kléber Aparecido da. Linguística aplicada, crenças e formação de professores na contemporaneidade. In: SANTOS, Leandra Ines Seganfredo; SILVA, Kléber Aparecido da. Linguagem, ciência e ensino: desafios regionais e globais. Campinas, SP: Pontes Editores, 2013. p. 19-40.

VIEIRA-ABRAHÃO, Maria Helena. A formação de professores de línguas: passado, presente e futuro. In: SILVA, Kléber Aparecido da. (Org.) Ensinar e aprender línguas na contemporaneidade: linhas e entrelinhas. Campinas: Pontes Editores, 2010. V. 1, p.225-232. (Coleção Novas Perspectivas em Linguística Aplicada).

VIEIRA-ABRAHÃO, Maria Helena. A formação de professores de línguas de uma perspectiva sociocultural. Signum: Estud. Ling., v. 15, n. 2 p. 457480 , 2012.

Disponível em: <http://www.uel.br/revistas/uel/index.php/signum/article/view/12736>. Acesso em: 29 abr. 2020. 
VYGOTSKY, Lev Semyonovich. A formação social da mente: o desenvolvimento dos processos psicológicos superiores. 7. ed. São Paulo: Martins Fontes, 1978/2007.

VYGOTSKY, Lev Semyonovich. Pensamento e linguagem. Martins Fontes, 1934/1999.

\section{Anexo 1}

\section{Atividade 3}

\section{Objetivos:}

- Permitir aos participantes compreender e se apropriar do conceito de professor reflexivo na perspectiva crítica;

- Relacionar e aplicar o conceito em questão às representações de professores de inglês encontradas no filme assistido.

\section{Materiais:}

Não apresenta.

\section{Procedimentos:}

- A partir da leitura prévia do texto Professor Reflexivo: construindo uma crítica (Pimenta, 2002), o professor deve considerar as perguntas a seguir:

1. Qual a sua concepção do que venha a ser "professor reflexivo"?

2. De que maneira a autora do texto procura definir o construto "professor reflexivo"?

3. Considerando o filme $O$ Substituto, você descreveria o protagonista do filme, o professor de inglês Henry Barthes, como "reflexivo"? Por quê? Que cenas do filme podem ilustrar isso?

4. Que outros professores podem ser considerados reflexivos no filme? Por que? Quais cenas podem comprovar sua resposta?

5. A crítica desenvolvida por Pimenta (2002) em relação às reflexões até então realizadas sobre o conceito de professor reflexivo salienta a necessidade de a reflexão deixar de ser apenas um ato individual e alcançar dimensões mais públicas e éticas. Nesse sentido, consideremos a citação a seguir a fim de relacioná-la com o contexto educacional apresentado no filme O Substituto. 
"Por um lado as finalidades educativas apresentam um discurso de preparar para a vida adulta com capacidade crítica em uma sociedade plural. Por outro, o trabalho docente e a vida da escola se estruturam para negar estas finalidades. É nesse paradoxo que os professores, para resistir às pressões que o contexto social e institucional exercem sobre eles, acabam reduzindo suas preocupações e suas perspectivas de análise aos problemas internos da aula. A compreensão dos fatores sociais e institucionais que condicionam a prática educativa e a emancipação das formas de dominação que afetam nosso pensamento e nossa ação não são espontâneas e nem se produzem naturalmente. São processos contínuos de descoberta, de transformação das diferenças de nossas práticas cotidianas" (PIMENTA, 2002, p. 27-28).

Com base no exposto, como você vê o personagem Henry Barthes e a reflexão que ele realiza na escola representada no filme em relação à sua prática e à de seus colegas de trabalho (professores), bem como em relação aos seus alunos e ao contexto social mais amplo do qual a escola faz parte? 6. Em nosso curso o filme tem sido tomado como um gênero multimodal que por estar sendo aplicado à formação de professores pode funcionar como um instrumento deflagrador da prática crítico-reflexiva. Você concorda que o filme $O$ Substituto estimulou a sua reflexão crítica? Por quê? De que maneira?

7. Você poderia mencionar algumas reflexões que você pôde exercitar durante a sessão de visionamento do filme $O$ Substituto?

8. Há algum outro assunto que você gostaria de comentar? Qual?

\section{Anexo 2}

\section{Entrevista focalizada após sessão de visionamento do filme $O$ Substituto}

01. O que mais impressionou você nesse filme?

02. Como você se sentiu em relação à sequência/parte introdutória do filme, na qual são mostrados vários professores contando como se tornaram professores?

03. E com relação à identidade assumida pelo professor Henry Barthes, ou seja, uma identidade de professor substituto, que optou por não criar vínculos com nenhuma escola e alunos?

04. Que contribuições novas esse filme trouxe a você? 
05. O que você pensa a respeito da postura profissional, bem como das atitudes do professor Henry Barthes em relação à sua própria vida, à profissão, à escola e aos seus alunos?

06. Agora que vocês tocaram nessa questão, por que vocês escolheram ser professores de línguas?

07. Como sua experiência como aprendiz de línguas e com seus professores de línguas influenciaram a escolher essa profissão?

08. Que professores de línguas você tem até hoje como referência? Em sua opinião, o que você destaca da ação deles? Por que eles se tornaram inesquecíveis para você?

09. Na época em que você cursou a educação básica e/ou na graduação houve (ram) algum (uns) professor (es) que tinha (m) uma identidade ou adotava (m) metodologias semelhantes à dos professores presentes no filme?

10. Que fatos marcantes ocorreram em sua vida que podem estar ligados ao seu interesse pela língua que você escolheu ensinar e à sua opção por ser professor dessa língua?

11. Que tipo de dificuldade você encontra ou imagina encontrar em sua atuação como professor?

12. Quando falamos de identidade profissional do professor de línguas o que vem à sua mente?

13. Qual é o seu sentimento em relação à profissão "professor de línguas"?

14. Em relação ao filme, percebe-se que o vermelho, bem como algumas imagens em desenho animado, chamam a atenção do espectador insistentemente. Como você interpreta o uso do vermelho no filme? E dos desenhos animados?

15. Relembrando a sequência final do filme, na qual o professor Henry Barthes é mostrado em meio a uma sala de aula bagunçada enquanto uma voz em off (certamente a de Henry) lê um trecho do livro A Queda da Casa de Usher do escritor americano Edgar Allan Poe, que reflexão é possível fazer?

16. Durante a sessão de visionamento do filme foi possível a você refletir criticamente sobre sua identidade, sobre a identidade de professor de língua representada pelo professor Henry Barthes e sobre a identidade da profissão "professor de línguas"?

Recebido em: 12/08/2019

Recebido em versão corrigida: 09/06/2020

Aceito em: 16/06/2020 
O cinema como prática social...

Title: Cinema as social practice: the genre film in language teacher criticalreflective education 